\title{
North-East Estonian coastal sea: recovery from the past anthropogenic pressure and new stressors on the background of natural variability
}

\author{
Ü. Suursaar, R. Aps, I. Kotta \& O. Roots \\ Estonian Marine Institute, University of Tartu, Estonia
}

\begin{abstract}
The heavily industrialized NE part of Estonia has been an environmental hot spot for decades. The oil shale industry, thermal power plants, a cement factory and a Soviet-era depository of radioactive wastes have seriously impacted virtually every component of the environment. This study focuses on environmental changes in the coastal sea, which comprises the southern part of the Gulf of Finland. It is based on national marine monitoring data (since 1968), as well as on recent in situ measurements on hydrodynamics, pollution spread, and on bottom habitat recovery. Starting from the 1990s, improvement of the water quality in the Gulf of Finland is evident. After re-orientation into market economy, substantial economic recession took place in Estonia in the 1990s. The pollution load from both industrial sources and from Narva River decreased. On the other hand, new water protection directives were introduced. However, together with economic growth in the 2000s, some new threats arose, e.g. in relation with the construction of ports at Kunda, Muuga, Sillamäe, and a new pulp mill at Kunda. The replacement of oil shale-based energetics with a nuclear power plant is currently under discussion.
\end{abstract}

Keywords: monitoring, trends, pollution load, pollution spread, eutrophication, recovery of habitat, Baltic Sea.

\section{Introduction}

The coastal marine environment is a vital economic and cultural resource for the population around the Baltic Sea. However, it is seriously impacted by many 
natural and human factors. An important constituent in implementing the EC Marine Strategy and Maritime Policy in the Baltic Sea is the elaboration of the ecosystem approach to the management of human activities in the European regional seas, and safeguarding the sustainable use of the Baltic ecosystem's goods and services. Due to the extensive coastal line and long traditions of seafaring, marine issues have always been important for Estonia. However, in the heavily industrialized NE part of Estonia, the oil shale industry, power plants, a cement factory and a depository of radioactive wastes have seriously impacted virtually every component of the environment [1-4]. This study focuses on environmental changes in the coastal sea, which comprises the southern part of the Gulf of Finland, and also on important shifts in economy, pollution load and social reception of environmental issues over recent decades. The issue also involves some important aspects of natural variability; decadal changes in hydrological conditions (water temperature, salinity, oxygen content, currents, upwelling, ice conditions) have influenced self-purification and pollution spread.

The aims of the paper are to analyse the environmental changes in the study area during the last 30-40 years, to assess the risks originated from the area for the Baltic Sea, and to identify the main problematic branches of economy and locations, important stressors and ingredients in the past, present and future.

\section{Material and methods}

\subsection{Data on pollution load}

Published pollution load compilations [3] and some overview papers [5, 6] were used to assess the main pollution sources along the North Estonian coast as well as history of their control (see also Table 1).

Table 1: Data on major municipal and industrial sewage treatment plants along the northern coast of Estonia [6].

\begin{tabular}{|l|r|r|l|}
\hline Treatment plant & $\begin{array}{l}\text { Construction/ } \\
\text { reconstruction }\end{array}$ & $\begin{array}{l}\text { Q }(1000 \\
\left.\mathrm{m}^{3} / \mathrm{yr}\right)\end{array}$ & $\begin{array}{l}\text { Remarks on treatment } \\
\text { procedure and efficiency \% }\end{array}$ \\
\hline $\begin{array}{l}\text { Tallinn Pulp and Paper } \\
\text { Mill }\end{array}$ & $-/ 1992$ & 15400 & $\begin{array}{l}\text { Untreated wastewater } \\
\text { outlet, closed in 1992 }\end{array}$ \\
\hline Tallinn town & $1984 / 1993$ & 46700 & Mech-chem-biol. 90\% \\
\hline $\begin{array}{l}\text { Kehra Pulp and Paper } \\
\text { Mill }\end{array}$ & $1977 / 1997$ & 11300 & $\begin{array}{l}\text { Mech-biol., earlier } \\
\text { untreated discharges }\end{array}$ \\
\hline $\begin{array}{l}\text { Maardu Chemical } \\
\text { Company }\end{array}$ & $1978 / 1985$ & 12900 & Floto effluent, mech-biol. \\
\hline $\begin{array}{l}\text { Kohtla-Järve Chemical } \\
\text { Company }\end{array}$ & $1957 / 1982$ & 34700 & $\begin{array}{l}\text { Different procedures } \\
\text { depending on effluent }\end{array}$ \\
\hline $\begin{array}{l}\text { Kiviõli Oil Shale and } \\
\text { Chemical Company }\end{array}$ & $1968 / 1982$ & 2200 & $\begin{array}{l}\text { Grit chamber, oil traps, } \\
\text { settling; Closed in 1994 }\end{array}$ \\
\hline Kunda Cement Factory & $1972 / 1997$ & 220 & Aeration tanks \\
\hline Kohtla Järve town & $1957 / 1999$ & 6300 & Mech-biol. 80\% \\
\hline Narva town & $1967 / 1983$ & 10900 & Mech-biol. 80\% \\
\hline
\end{tabular}




\subsection{Monitoring of the coastal sea}

For analysis of water quality in the North Estonian coastal sea we used the monitoring database of the Estonian Marine Institute. It contains both the digitised historical data for the period (1968-1993) when the marine monitoring were carried out by the predecessors of the Estonian Meteorological and Hydrological Institute [1], as well as the data from the new revised national monitoring programme $[6,7]$.

Regular pollution control in some parts of the coastal waters of Estonia (mainly ports) began in 1967, after the endorsement of the General Plan for Water Use and Protection of the USSR. Since 1968, regular observations on hydrological and hydrochemical parameters are carried out around the coasts of Estonia. Until 1991, these observations were carried out in about 40-50 stations by the former Estonian Hydrometeorological Service within the monitoring system of the Soviet Union. The only station of the highest priority (station 57a), was located in the southern part of the Tallinn Bay, the area which was strongly influenced by sewage of Tallinn Paper Mill and port. It was monitored in every 10 days throughout the year. The other stations were monitored mostly 3-6 times during the ice-free period. The variables measured included water temperature, salinity, $\mathrm{pH}, \mathrm{O} 2, \mathrm{O} 2 \%$, nutrients $\left(\mathrm{N}-\mathrm{NO}_{2}, \mathrm{~N}_{-} \mathrm{NO}_{3}, \mathrm{~N}-\mathrm{NH}_{4}, \mathrm{P}_{-} \mathrm{PO}_{4}\right.$ : since $1984 \mathrm{P}_{\text {tot }}$ and $\mathrm{Si}_{-} \mathrm{SiO}_{4}$ ), oils, phenols, detergents, and episodically some other ingredients (DDT, PCB, lignine, heavy metals, alkalinity).

Since 1979, activities within the international Baltic Monitoring Programme (BMP) by HELCOM were started. Evaluation and statistical comparison between the BMP and the national monitoring data revealed very large variability, systematic biases, and frequent incompatibility due to different sampling and analysing standards [1]. Starting from 1991, revision of the national monitoring began. Since 1993 marine monitoring is carried out by the Estonian Marine Institute. The present programme is based on the requirements of the BMP, the new Baltic Sea Programme from 1998 (COMBINE), and the European Water Framework Directive. It includes the sub-programmes of (1) monitoring of eutrophication of the coastal sea, (2) monitoring of phytobenthos assemblages in the coastal zone and (3) monitoring of priority hazardous substances $(\mathrm{Cd}, \mathrm{Hg}, \mathrm{Pb}, \mathrm{Cu}, \mathrm{Zn}, \mathrm{HCH}, \mathrm{DDT}, \mathrm{PCB})$ in the marine environment.

\subsection{In situ field measurements and special monitoring contracts}

According to special monitoring contracts, nearly 50 surveys in the coastal sea near "hot spots" of Muuga, Kunda and Sillamäe were carried out in 2003-2008. Usually they included CTD-probing and water samplings for $\mathrm{N}_{\text {tot }}, \mathrm{P}_{\text {tot }}, \mathrm{pH}$, $\mathrm{BOD}_{7}, \mathrm{COD}, \mathrm{Chl} a$, and suspended matter. Monitoring of bottom habitat was performed annually along transects. For investigation of hydrodynamic processes, which are responsible in pollution spread, modelling suite of Seatrack Web and in situ special measurements were used. The web-based (http://seatrack.smhi.se/seatrack/, see also e.g. [8]) modelling system has a grid spacing of 3 nautical miles and it is forced by realistic meteorological data. The special hydrodynamic measurements were carried out by the means of 
oceanographic complex called RDCP-600 by AADI. The Recording Doppler current profiler applies the Doppler effect to measure vertical distribution of velocity. It also measures water temperature, turbidity, conductivity, oxygen and waves. The instrument was deployed at seabed near Kunda during three periods (10 Aug.-14 Sept. 2006, 16 Oct.-24 Nov. 2006, 13 Aug.-17 Sept. 2008), and once (27 Oct.-5 Nov. 2003) in the Muuga Bay (Fig. 1).

\section{Study area}

The North Estonian coastal sea stretches for about $300 \mathrm{~km}$ from west to east along the Gulf of Finland (Fig. 1), which has an area of $29500 \mathrm{~km}^{2}$ and average depth of $37 \mathrm{~m}$. The Gulf receives a relatively large pollution load both from rivers (Neva, Narva, Kymijoki), as well as from industries and municipalities [3].

\subsection{Hydrodynamic dilution conditions in the coastal sea}

The circulation scheme in the Gulf of Finland is mostly wind-driven and although certain statistical long-term patterns can be found [9], it is quite variable. The northern coast of Estonia has relatively straight coastline where good mixing conditions due to waves and currents prevail [10].

The Gulf of Finland is one of the world's most intensive shipping areas. While the grid-spacing in traditional oil-slick models, including Seatrack Web allows the simulation of the general hydrodynamic situation of the sea area with reasonable degree of approximation, they fail in resolving meso-scale hydrodynamic phenomena, such as upwelling and the related baroclinic coastal jets. The cross-section extension of coastal upwelling is mainly determined by the baroclinic Rossby radius, which in this part of the Baltic Sea is $1-5 \mathrm{~km}$ [9].

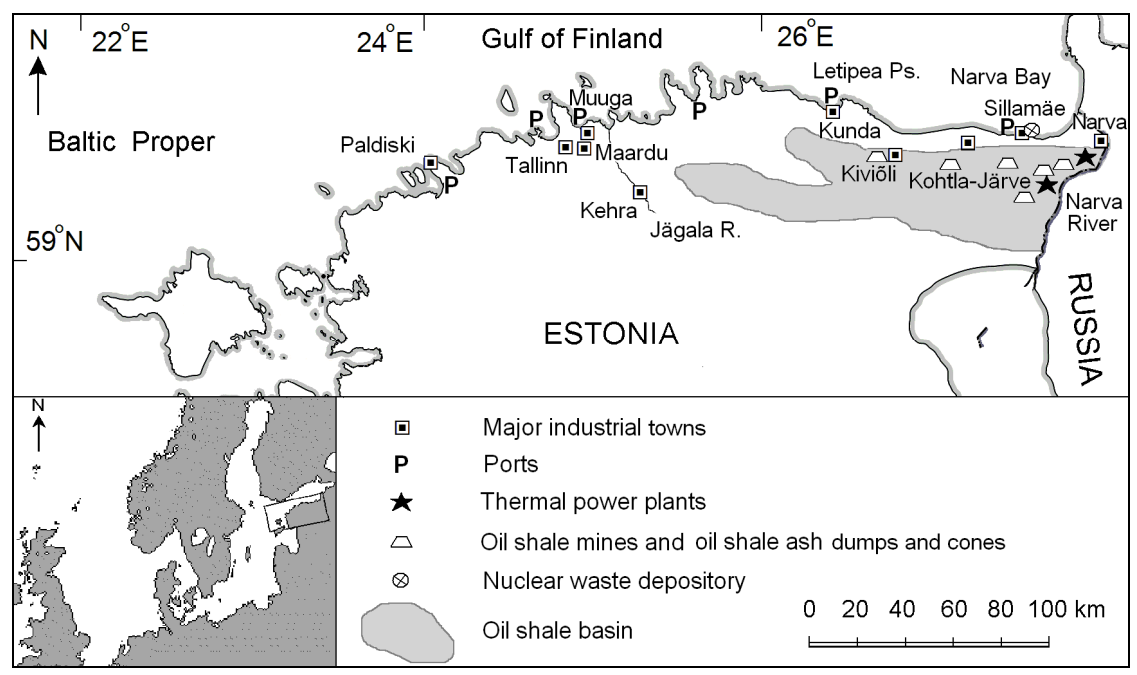

Figure 1: $\quad$ North Estonia and the southern part of the Gulf of Finland. 
Out of four, two measuring sets of our multi-layer current dynamics obtained with RDCP included extensive upwellings: on July-August 2006 [11] and on August-September 2008. According to MODIS sea surface temperature images and modelling, the frequency of occurrence of upwelling (or downwelling) can be as much as $30 \%$ in some suitable (straight) coastal sections of the Gulf of Finland [9]. As a general rule, persistent westerlies may evoke upwelling along the Finnish coast, while easterlies and north-easterlies along the North Estonian coast. Baroclinic coastal jet appears due to rise in pycnocline during upwelling. We discovered that in upwelling-forming wind conditions, relatively modest eastwinds can produce a surprisingly fast westward coastal jet [11]. The width of the stream can be only a few kilometres, but the velocity can reach up to $1 \mathrm{~m} / \mathrm{s}$ in the upper layer. In case of accidental spills either in the pulp mill or in nearby ports of Kunda and Sillamäe, the alongshore travel speed of a spill may reach 50-100 km per day. As the second important inference for possible fate of pollution, due to low water temperatures (frequently as low as $4 \ldots 10{ }^{\circ} \mathrm{C}$ as opposed to normal summertime water temperatures around $20{ }^{\circ} \mathrm{C}$ in adjacent waters), the degradation of pollutants is much slower. As a well-known first approximation of dynamics of bio-chemical processes, the van't Hoff law states, that the rate of chemical reactions increases between two- and threefold for each $10{ }^{\circ} \mathrm{C}$ rise in temperature. The degradation speed may also be slowed down due to lowered oxygen content in the up-welled water, which originates from the deeper, sometimes nearly stagnant layers of the Gulf.

\section{Identification of the main pollution sources and risks}

\subsection{Oil shale mining, power and the chemical industry}

Oil shale mining and oil shale-based power and chemical industry has been the main cornerstone of the Estonian economy for decades. The largest commercially exploited oil shale deposit in the world has an area of $2884 \mathrm{~km}^{2}$. Presently, 2 underground mines and 2 huge open pit mines are in operation (Fig. 1). The majority of the mined oil shale (15 million tons/yr) is used for electricity generation in two thermal power plants near Narva (Fig. 1) with total capacity of 2900 MW [12]. As oil shale is a low-grade fossil fuel, each year about 4-5 million tons of oil shale ash is washed through and subsequently dumped near the power plants. The large and first-evident pressure on landscapes has been somewhat mitigated. For example, the extensive afforestation of exhausted opencast mines began in 1960 and about $80 \%$ of such mines (totalling 12,900 ha) have been forested by 2005 [4]. Partial replacement of oil shale-based power production with more sustainable energetic is currently under discussion in the Estonian society. The main alternatives to the oil shale, however, seem to be wind energy (too costly and actually non-sufficient) and nuclear energy.

Mining and cooling effluents have primarily impacted North Estonian rivers. For coastal sea, however, the main risks appear from the effluents of oil shalebased chemical industry and oil extraction. In economic peak years of 1980s, Kohtla-Järve and Kiviõli chemical companies (Table 1) discharged substantial 
amounts of $\mathrm{BOD}_{7}(8500 \mathrm{t} / \mathrm{yr}), \mathrm{P}_{\text {tot }}(150 \mathrm{t} / \mathrm{yr}), \mathrm{N}_{\text {tot }}(5800 \mathrm{t} / \mathrm{yr})$, but also phenols (650 t/yr), oils, and different hazardous substances. Due to more than two-fold decrease in production, as well as construction and reconstruction of wastewater treatment plants over the last two decades, the pollution load has decreased to the coastal sea (Tables 1 and 2). Still, in Estonia the generation of hazardous waste per capita in a year (6.4 tons in 2007) is the highest among European countries, the main reason for which is oil shale treatment waste [12].

\subsection{Pulp and paper industry}

In North Estonia, already since the beginning of the $20^{\text {th }}$ century, large pulp and paper mills discharged, either directly or via rivers, to the Gulf of Finland. The Tallinn mill had an annual production of about $68000 \mathrm{t}$ of sulphite cellulose, and the Kehra mill had $52000 \mathrm{t}$ of sulphate cellulose. The closure of these mills in the 1990s was a result of changing economical prospects after regaining independence, but also of altered environmental requirements. The affected coastal areas featured low $\mathrm{pH}$ and oxygen (Fig. 2), and high $\mathrm{N}-\mathrm{NH}_{4}$ content. The quality of the water also failed markedly by organoleptic standards. Today, most pulp mills around the Baltic Sea utilize a chlorine-free bleaching process. However, about $50 \%$ of the total organochlorine inputs from pulp mills since the early 1940s still reside in the Baltic Sea - mainly in the bottom sediments [13].

In the Kunda region, the major pollution source was a large cement factory. The emission of the factory has considerably decreased over the recent decade.

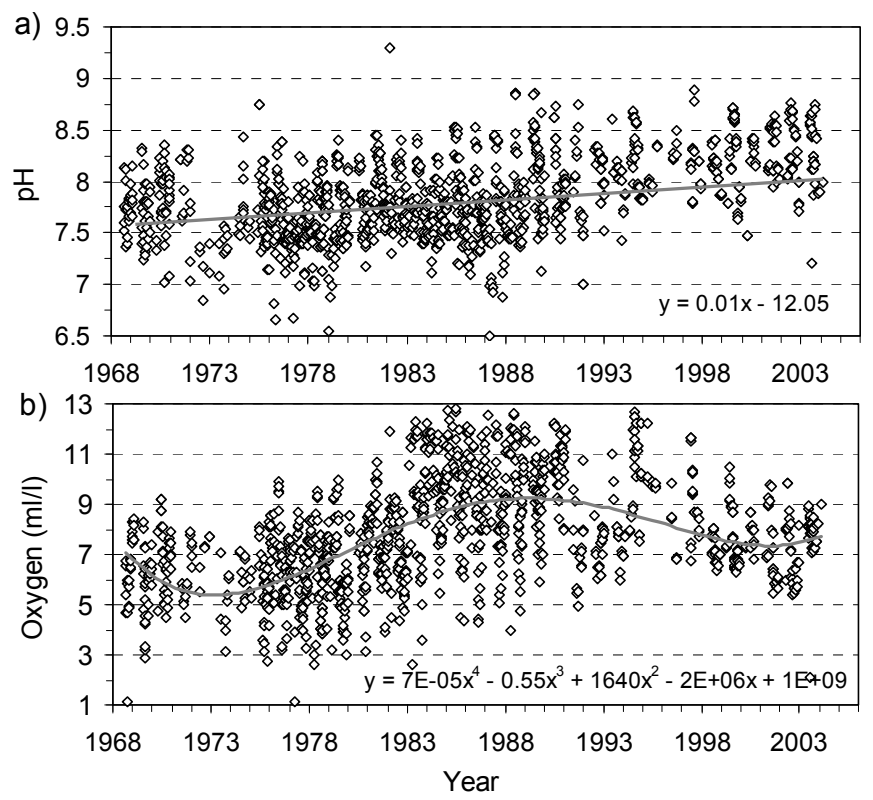

Figure 2: $\quad$ Variations in $\mathrm{pH}$ and oxygen in the southern part of Tallinn Bay. 
Table 2: $\quad$ River discharges of organic matter and nutrients into the Gulf of Finland $(\mathrm{t} / \mathrm{yr})$ in different periods $[3,5,12]$. The rivers of Narva $\left(12.6 \mathrm{~km}^{3} / \mathrm{yr}\right)$ and Jägala $\left(0.3 \mathrm{~km}^{3} / \mathrm{yr}\right)$ are the largest in the North Estonia.

\begin{tabular}{|l|r|r|r|r|r|}
\hline River & \multicolumn{1}{|c|}{$\mathrm{BOD}_{7}$} & \multicolumn{1}{|c|}{$\mathrm{N}_{\text {tot }}$} & \multicolumn{1}{c|}{$\mathrm{NO}_{3}$} & $\mathrm{P}_{\text {tot }}$ & $\mathrm{PO}_{4}$ \\
\hline Narva R.: 1975-76 & 18000 & 3900 & & 360 & \\
$1982-84$ & 35000 & 15000 & 9200 & 670 & 290 \\
2003 & 21000 & 5200 & 1300 & 530 & 230 \\
\hline Jägala R.: 1982-84 & 1000 & 930 & 600 & 30 & 10 \\
2003 & 670 & 640 & 390 & 13 & 6 \\
\hline Gulf of Finland (1982-84) & 350000 & 94000 & 57000 & 5800 & 2600 \\
\hline
\end{tabular}

On September 2006, a new aspen pulp mill, Estonian Cell, was opened near Kunda (Fig. 1). The factory features sulphur free production and the purified wastewater is conducted into the Gulf of Finland at a depth of $10 \mathrm{~m}$.

\subsection{Narva River}

According to various pollution load assessments, about $70-80 \%$ of the organic substances and nutrients enter the Gulf of Finland via rivers [3, 5]. The main contributor is the Neva River in Russia. The second largest, the Narva River, drains the catchment area of $56200 \mathrm{~km}^{2}$. Due to recession in agriculture, but also due to the commissioning of municipal wastewater treatment plants e.g. in Narva and Tartu, the river discharges have decreased (Table 2).

\subsection{Sillamäe}

Sillamäe, now a success story, was potentially one of the most serious threats for the whole Baltic Sea environment. Sillamäe town has founded together with construction of a highly specialized chemical and metallurgy plant in 1946. It was a closed town in 1947-1991, where fuel rods and nuclear materials for the Soviet nuclear power plants and weapons were produced. At first, uranium was mined in the same location (from dictyonema argillite), later it was imported mainly from Czechoslovakia. Uranium enrichment was finished in 1989, since then enrichment of rare metals (such as niobium) at AS Silmet is going on.

On the immediate shore of the Gulf of Finland, a 50 ha nuclear waste depository grew, where probably some 1200 tons of uranium, 800 tons of thorium enrichment residuals and other hazardous substances are buried. The coast near depository became destabilized and wave activity allowed the erosion to reach the depository's protective dam. It has been known only since 1989 that annually some 4000 t of ammonia has leaked into the Gulf of Finland through the dam. The closure and sanitation of the depository in 1998-2008 became one of the highest priority environmental projects over the whole Baltic Sea basin. In 2005, a new port was opened in Sillamäe. It has a jetty for oil tankers, and a regular ferry service was established between Sillamäe and Kotka, Finland. 


\section{Discussion}

\subsection{Long-term changes and natural variability}

When assessing changes in the sea, one must bear in mind that the changes caused by human activity are superimposed with natural ones. E.g., manifestations of climate change appear as "natural" background for local anthropogenic changes. Water temperature, salinity, oxygen, nutrient concentrations and $\mathrm{pH}$, are influenced via riverine inflow and water exchange in the Danish Straits by large-scale atmospheric variability features above North Atlantic $[1,2]$. In the Gulf of Finland, the temperature below halocline decreased during the last 20-30 years. Salinity trend is increasing again since mid-1990s (Fig. 3a). Irregularity of advectional inflows of more saline and oxygen poor water masses from the Baltic Proper connected with weakening stratification has improved oxygen conditions (Fig. 3b). Still, extensive anoxic conditions frequently occur at the sediment-water interface in the Gulf of Finland [2], reflecting high levels of accumulated organic matter in the sediments. Oxygen deficiency has already affected negatively the condition of bottom life [14].

The variations in nutrient concentrations show pronounced seasonal, vertical and inter-annual variability (Figs. 3 and 4). Such factors as infrequent monitoring versus large natural variability, changes in analytical methods and mixed data from different laboratories may overshadow real tendencies [1]. It seems that the prevailing tendencies towards a decrease in phosphorus concentrations and increase in nitrogen concentrations in the Gulf of Finland from the 1970s to the early 1990s were altered by the opposite tendencies in the 1990s (Figs. 3 and 4).

In many parts of the Estonian coastal waters (e.g. in Gulf of Riga) negative nutrient trends occur since 1990s [7]. In Narva Bay a decrease from 1980s to 1990 s likely altered with a new increase in 2000s (due to lack of winter data on the basis of summer ones; Fig. 4). Despite a $25-30 \%$ decrease in nutrient load since 1980 s, which is mainly a result of economic recession and restructured agriculture, the connection between load reduction and possible improvement in the water quality is not straightforward. One of the reasons is that internal nutrient fluxes (both advective, between different sub-basins, and from bottom sediments) can effectively counteract decreases in external load [15].

The trends for water quality improvement are more evident in the immediate coastal zone of industrialized NE Estonia and in Tallinn Bay (Figs. 2 and 4). For long time water quality at the station 57a (Fig. 2) was the most "abnormal" in the Estonian coastal waters. High content of ammonia, phenols and oils, relatively high concentrations of other nutrients, very low oxygen and $\mathrm{pH}$ values were the main evidences for that. The situation in the southern part of Tallinn Bay has improved considerably since launching the central water treatment plant of the city, and closing paper mill in 1993. One of the most evident indicators for the normalization, the $\mathrm{pH}$ trend shows values around 8.2 versus old 7.6 (Fig. 2a). Also oxygen conditions have improved (Fig. 2b), which show improvement both in the water column and bottom sediments. However, at present it is unknown how large quantity of nutrients was deposited in the sediments of the bay. 
Although eutrophication is considered the main ecological problem of the Baltic Sea [2], some priority hazardous substances should be monitored, especially in industrialized regions. The results of the corresponding monitoring sub-programmes have shown that during the last decades the state of the environment regarding such substances has continuously improved [16]. At present, the list of priority hazardous substances of Estonia should include phenols, $\mathrm{Ba}$, and heavy metals $(\mathrm{Cr}, \mathrm{Cu}, \mathrm{Ni}, \mathrm{Zn})$ together with their compounds [17]. However, if necessary, parameters can be added or removed from the list.
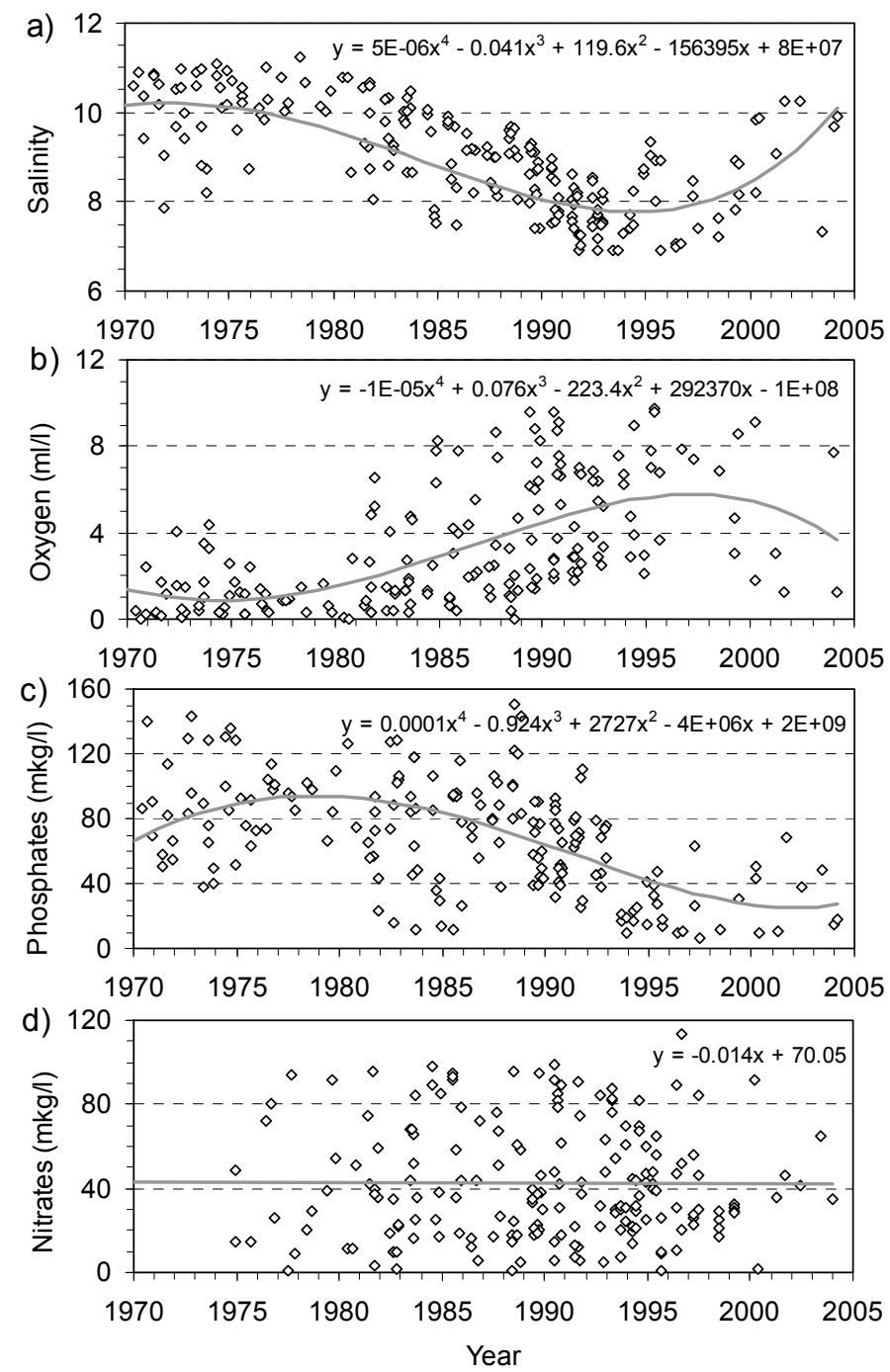

Figure 3: Long-term variations in some water quality parameters in the deep layers $(>70 \mathrm{~m})$ of the Gulf of Finland. 


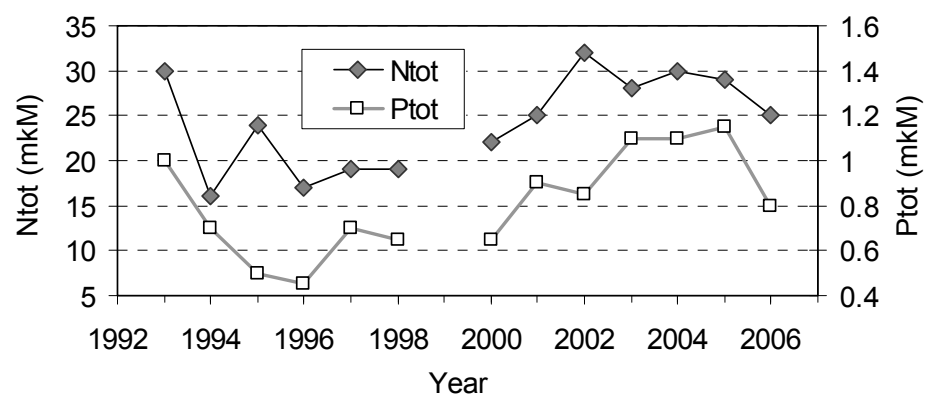

Figure 4: Trends in $\mathrm{N}_{\text {tot }}$ and $\mathrm{P}_{\text {tot }}$ concentrations in the surface waters of Narva Bay in 1993-2007 (annual summer data averages from [6]).

The concentrations of the heavy metals are currently very low as compared to the 1980s. As a direct impact, annual emissions of heavy metals from the Baltic Sea countries decreased by about $20 \%$ for $\mathrm{Cd}, \mathrm{Hg}$ and $\mathrm{Pb}$ in $1996-2000$ [3]. The concentrations of hazardous substances in sediments and surface waters remain low, the concentrations in fishes in the Estonian coastal sea are below the standards established by the FAO/WHO for food and they are decreasing [16].

\subsection{Recent developments: recovery versus new threats}

Without doubt, many positive developments have occurred in the environment of the North Estonian coastal sea over the last 10 the connection between load reduction and possible improvement in the water quality is not straightforward. 20 years and recovery of bottom and pelagic habitat is evident. However, starting from the end of 1990s, a new economic growth has occurred. Estonian GDP rose two-fold [12]; some new ports and new factories have been put into operation. According to our results on monitoring of the possible effects of the effluents, the impact of the new factories, such as Kunda pulp mill on the coastal sea is modest and the environmental risks are well handled. Due to strict environmental norms and good hydrodynamic dilution conditions for effluents, the impact on the abiotic environmental components is barely visible on the background of normal variability. The influence of natural resuspension during storms is larger than considered earlier [6]. The concentrations of nutrients seem to be a bit higher than in the open Gulf of Finland. However, according to the biological surveys, while recovery of bottom habitat from the past economic pressure has occurred in the most parts of Narva Bay, there may be small newly introduced changes in bottom vegetation and zoobenthos in the vicinity of the outlet near Letipea Peninsula [6], as the discharges might have impaired underwater light conditions and settling may bury benthic organisms [14].

The planned Nord Stream gas pipe between Russia and EU in the bottom of the Baltic Sea, as well as newly constructed ports at Paldiski, Muuga, Kunda and Sillamäe have introduced some new risks. Oil transit has grown markedly through the ports over the last 10 years and due to increased traffic possibility of shipping accidents is high. For example, relatively "small", but nevertheless 
quite serious oil spills (e.g. tanker Alambra accident in Muuga Bay in 2000, collision and sinking of a cargo vessel Runner 4 in the Gulf of Finland in 2006) initiated new oil spill combat plan. The spills are now monitored by the aircraftbased SLAR- and Lidar-systems and modelled using Seatrack Web. New oilcombating vessels were launched or bought in 2006 and 2009. Finally, North Estonian coast, or more precisely, Pakri, Letipea and Sillamäe are the possible construction sites for a future nuclear power plant for Estonia.

\section{Conclusions}

Several overlapping tendencies have appeared in the coastal waters of North Estonia. First of all, long-term improvement of the water quality in the Gulf of Finland due to decreased pollution load and self-purification is evident. However, the connection between load reduction and possible improvement in the water quality is not always straightforward. Also, the improvement did not occurred spontaneously. It is a reflection of efforts for reduction of pollution load both on national and international level, endorsement of tight pollution control mechanisms, taken remedial actions and improvement in environmental legislation. Still, oil shale industry remains the main pollution source in Estonia. Together with economic growth in 2000s, some new threats arose in relation with construction of a new pulp mill at Kunda, and ports at Kunda, Muuga and Sillamäe. Oil transit has increased markedly and a new nuclear power plant will be eventually built on the shore of the Gulf of Finland. Continuous efforts should be paid to keep these new developments just as potential threats that are secured and mitigated by efficient pollution control and monitoring.

\section{Acknowledgements}

The study was supported by the Estonian Science Foundation through grant No 7609 and target financing programme SF0180104s08.

\section{References}

[1] Suursaar, Ü. Estonian marine monitoring 1968-1991: Results and evaluation. Finnish Marine Research, 262, pp. 123-134, 1994.

[2] HELCOM, The Baltic marine environment 1999-2002. Balt. Sea Environ. Proc., 87, Helsinki, 2003.

[3] HELCOM, The Fourth Baltic Sea Pollution Load Compilation (PLC-4). Balt. Sea Environ. Proc., 93, Helsinki, 2004.

[4] Lõhmus, K., Kull, A., Truu, J., Truu, M., Kaar, E., Ostonen, I., Meel, S., Kuznetsova, T., Rosenvald, K., Uri, V., Kurvits, V. \& Mander, Ü., The reclamation of the North Estonian oil shale mining area. Multifunctional land use: Meeting future demands for landscape goods and services, eds. Ü. Mander, H. Wiggering \& K. Helming, Springer: Berlin, Heidelberg, pp. 378-401, 2007. 
[5] Loigu, E., Leisk, Ü. \& Iital, A., Pollution load of the Gulf of Finland via rivers (since 1984). Water protection of the Gulf of Finland and Estonian waterbodies (1945-2003), ed. H.-A. Velner, TUT Press: Tallinn, pp. 91104, 2005.

[6] Martin, G., Jaanus, A., Põllumäe, A. \& Kotta J., Monitoring of the coastal sea. Estonian environmental monitoring 2004-2006, ed. K. Väljataga, Ministry of Environment: Tallinn, pp. 72-76, 2008.

[7] Suursaar, Ü., Astok, V. \& Kotta, J., Monitoring and assessment of the Estonian coastal sea in 1945-2003. Water protection of the Gulf of Finland and Estonian waterbodies (1945-2003), ed. H.-A. Velner, TUT Press: Tallinn, pp. 129-144, 2005.

[8] Kostianoy, A.G., Ambjorn, C. \& Soloviev, D.M., Seatrack Web: A numerical tool to protect the Baltic Sea marine protected areas. 2008 IEEE/OES US/EU-Baltic International Symposium, IEEE: New York, pp. 7-12, 2008.

[9] Soomere, T., Myrberg, K., Leppäranta, M. \& Nekrasov, A., The progress in knowledge of physical oceanography of the Gulf of Finland: a review for 1997-2007. Oceanologia, 50, pp. 287-362, 2008.

[10] Suursaar, Ü., Aps, R., Martin, G., Põllumäe, A. \& Kaljurand, K., Monitoring of the pulp mill effluents in the coastal waters of North Estonia. Water Pollution IX. Book Series: WIT Transactions on Ecology and the Environment, 111, eds. D.P. Rico, C.A. Brebbia \& Y.V. Estevel, pp. 217 226, 2008.

[11] Suursaar, Ü. \& Aps, R., Spatio-temporal variations of hydrophysical and chemical parameters during a major upwelling event in the southern coast of the Gulf of Finland in the summer of 2006. Oceanologia, 49, pp. 209228, 2007.

[12] Rohtla, R. (ed.), Monthly bulletin of Estonian statistics, 12/08. Statistics Estonia: Tallinn, 148 pp., 2009.

[13] Kankaanpää, H., Lauren, M., Saares, R., Heitto, L. \& Suursaar, Ü., Distribution of halogenated organic material in sediments from anthropogenic and natural sources in the Gulf of Finland catchment area. Environmental Science and Technology, 31, pp. 96-104, 1997.

[14] Kotta, J., Lauringson, V. \& Kotta, I., Response of zoobenthic communities to changing eutrophication in the northern Baltic Sea. Hydrobiologia, 580, pp. 97-108, 2007.

[15] Pitkänen, H., Lehtoranta, J. \& Raike, A., Internal nutrient fluxes counteract decreases in external load: The case of the estuarial eastern Gulf of Finland, Baltic Sea. Ambio, 30, pp. 195-201, 2001.

[16] Roose, A. \& Roots, O., Monitoring of priority hazardous substances in Estonian water bodies and in the coastal Baltic Sea. Boreal Environment Research, 10, pp. 89-102, 2005.

[17] Roots, O., Proposal for selection of national priority hazardous substances for Estonian surface water bodies. Ecol. Chemistry, 17, pp. 22-34, 2008. 